\title{
PEMBERDAYAAN GURU SMP MELALUI PELATIHAN DASAR HIPNOTERAPY DALAM PEMBELAJARAN DI SMP 1 ISLAM KOTA MALANG
}

\author{
Gumgum Gumelar ${ }^{1)}$, Erik $^{2}$ \\ Fakultas Pendidikan Psikologi, Universitas Negeri Jakarta \\ E-mail: ggumelar@unj.ac.id ${ }^{1)}$, erik@unj.ac.id ${ }^{2)}$
}

\begin{abstract}
The aim of this community service is to improve the teacher's ability to keep the concentration and focus from a student to maximize learning performance. This activity is done by creating a module and planning activities, determining the place of execution and transfer of learning (learning) on teachers in junior 1 Islam Malang East Java. This event as the beginning of an effort to measure the effectiveness of hypnotherapy as part of the skills of teachers in improving student's learning achievement. Benefits of devotion to the creation of the learning result and the productivity of teachers in the process of learning and teaching in the teacher for the children of students in Malang. East Java, also could become a foundation for the development of learning techniques.
\end{abstract}

Keywords: Hipnoteaching; Learning Process; learning process.

\begin{abstract}
ABSTRAK
Tujuan pengabdian masyarakat ini adalah bagian dari usaha untuk meningkatkan standar dan peningkatan kemampuan guru dalam menjaga konsentrasi dan fokus dari siswa didik sehingga mendapatkan hasil belajar yang maksimal. Kegiatan ini dilakukan dengan membuat modul dan perencanaan kegiatan, menentukan tempat pelaksanaan dan melakukan transfer of learning (proses pembelajaran) pada guru-guru di SMP 1 Islam Kota Malang Jawa Timur. Kegiatan ini sebagai awal dari usaha mengukur efektivitas dari hipnoteaching sebagai bagian dari ketrampilan guru dalam meningkatkan prestasi belajar sisiwa. Manfaat dari pengabdian ini agar terciptanya hasil belajar dan produktivitas guru dalam proses belajar dan mengajar pada guru bagi para anak-anak didik di Kota Malang erta menjadi landasan untuk pengembangan teknik pembelajaran.
\end{abstract}

Kata Kunci: Hipnoteaching; Guru ; metode pembelajaran; proses pembelajaran

\section{PENDAHULUAN}

Hipnotis oleh sebagian orang masih dipandang sebagai sesuatu yang kurang baik, padahal hipnotis adalah sesuatu yang bisa dibuktikan secara ilmiah, bahkan logis. Saat ini kita lihat cukup banyak penerapan hipnotis dalam kehidupan misalnya untuk kesehatan fisik, psikologis, dan hal-hal yang menyangkut patologi sosial.

Sejauh ini hipnotis dipandang sebagai bagian dari usaha untuk memperbaiki gangguan psikologis dan hiburan. Beberapa pandangan melihat hipnotis dan hipnotherapy dapat dilihat dari sisi positif seperti untuk pengembangan dan empowerment dalam peningkatan kapasistas individu, salah satunya melalui hipnoteaching.

21 | Jurnal Sarwahita Vol. 14 No. 01 Tahun 2017
Hipnoteaching sebagai bagian dari peningkatan kapasitas individu dimulai dengan memahami lebih jelas mengenai hipnosis. Hypnosis dapat diartikan sebagai sebuah kondisi relaks, fokus, atau konsentrasi, yang menjadi ciri khas kondisi tersebut, dengan pengertian lain kondisi hypnosis adalah kondisi atau keadaan saat manusia cenderung lebih sugestif dan ada sebuah fenomena trance yang terjadi akibat adanya tidur syaraf atau tidurnya pikiran bawah sadar seseorang.

Hypnosis melibatkan perhatian yang sangat terfokus yang disebut sebagai penyerapan (Tellegen dan Atkinson, 1974). Seseorang yang terhipnotis sebetulnya pada kondisi sangat terkonsentrasi yang sangat fokus. Jadi proses hipnotis adalah proses 
membimbing seseorang berpindah fokus dari eksternal ke internal (konsentrasi).

Menurut Rodli (2017) hypnosis juga dapat diartikan sebagai keadaan pikiran dimana pikiran menjadi berkurang dalam fungsi analitis logis yang memungkinkan seseorang masuk ke dalam keadaan tidak sadar (sub sadar/tidak sadar), yang tersimpan berbagai potensi internal yang dapat dimanfaatkan lebih jauh untuk meningkatkan kualitas hidup seseorang.

Pada prinsipnya untuk mengakses alam bawah sadar seseorang bisa dilakukan dengan menggunakan berbagai teknik. Semisal teknik verbal (sugesti), teknik relaksasi progresif, teknik penggunaan energi, teknik visualisasi, dan teknik mistik (supranatural, baik ilmu hitam maupun putih).

Menurut berbagai ahli, secara sederhana kita dapat mengatakan bahwa pikiran manusia terdiri dari dua fungsi : alam sadar (berpengaruh pada kehidupan kita sekitar $12 \%)$, dan alam bawah sadar (88\%). Artinya alam bawah sadar mengelola lebih banyak kehidupan kita. Ada ahli lain yang membedakan menjadi 3 (sadar, bawah sadar, dan tak sadar), namun untuk memudahkan kita sederhanakan saja hanya ada dua fungsi. Alam sadar berfungsi secara kritis memfilter segala informasi yang akan masuk ke otak, menimbang, memeriksa secara logis, menganalisis dan seterusnya. Sedangkan alam bawah sadar tidak melakukan fungsi itu, disini disimpan memori, disimpan pula programprogram dan pola prilaku kita, demikian juga mengatur berbagai fungsi organ tubuh.

Alam bawah sadar ini mirip anak kecil, ia tidak bisa membedakan antara realitas dan imajinasi. Pada saat kita rileks dan konsentrasi, secara otomatis alam bawah sadar ini akan terakses. Ini menjelaskan kenapa kreativitas munculnya pada saat kita rileks.

Gejala hipnotis bukan hal yang aneh. Setiap hari kita ini masuk dan keluar kondisi hipnotis/trance berkali-kali, hanya saja levelnya biasanya ringan. Misal saat kita nonton TV, dimana perhatian kita terserap sepenuhnya di TV, maka kita tidak sadar akan sekeliling dan menjadi sangat tersugesti oleh
TV. Pada saat kita melihat film seseorang yang diperkosa, maka kita akan sedih dan marah, padahal kita hanya melihat dalam film. Namun, sekali lagi, karena pada saat nonton TV kita rileks dan konsentrasi, maka fungsi bawah sadar menjadi mendominasi, dan alam bawah sadar tidak bisa membedakan antara realitas dan imajinasi. Maka kita menjadi terhanyut dan sedih.

Itu mirip dengan saat seorang dihipnotis, ia tahu bahwa ia bukan kucing, namun terus saja ia mengeong-ngeong, karena alam bawah sadar sudah mengijinkan si penghipnotis untuk memprogram-nya "menjadi" kucing. Sedangkan alam sadarnya sudah dibuat menjadi kurang berfungsi pada saat ia di induksi ke hypnosis state

Fenomena hipnotis/trance ringan juga terjadi setiap hari saat terhanyut membaca buku, nyetir di tol, mendengarkan musik klasik, pacaran sampai lupa waktu, sepuluh jam terasa sejam, dan seterusnya.

Masyarakat yang tidak mengetahui hipnosis mungkin saja telah mempraktekkan konsep hypnosis dalam kehidupan sehari-hari. Bahkan, mereka sudah bisa dikatakan sebagai maestronya. Orang-orang tipe seperti ini bisa digambarkan seorang guru yang piawai memberikan motivasi kepada peserta didiknya untuk semangat belajar, mampu mengajar dengan penyampaian yang mampu membuat peserta didik memusatkan perhatiannya kepada guru hingga membuat guru tersebut digandrungi peserta didiknya dan dianggap sebagai guru teladan sebenarnya telah mengaplikasikan teknik-teknik hypnosis dalam kehidupan sehari-hari.

Seorang ibu yang mampu meredam keinginan anaknya untuk berhenti bermain dan mampu membuat anaknya belajar di tengah anaknya sedang asyik bermain, seorang ustad atau ustadzah yang sangat digandrungi oleh jama'ahnya. Teknik yang dilakukan orang-orang yang dijelaskan di atas merupakan bagian dari teknik hypnosis, yaitu bagaimana memberikan informasi yang dapat menggugah dan menenteramkan hati orang lain.

Jurnal Sarwahita Vol. 14 No. 01 Tahun 2017 | 22 
Seseorang yang memang tahu, tapi salah tanggap, biasanya mereka enggan dengan dan takut untuk mendalaminya. Apalagi hal itu diperkuat dengan alasan-alasan kuat dalam agama tertentu, tradisi, adat istiadat, dan semacamnya. Dengan demikian, mereka menganggap bahwa lebih baik menjauhi halhal buruk daripada berkecimpung dengan halhal yang bisa membuat dirinya menentang ajaran yang telah ia percaya.

Pandangan seperti ini biasanya berlaku pada seorang yang mampu melakukan meditasi hingga menuju kondisi alpha dan tetha seperti contohnya motivasi diri, merelaksasikan tubuh dan pikiran orang lain, namun orang tersebut tidak mengakui apa yang dilakukan sering dianggap bukan dan bebas dari unsur hipnosis.

Sering kali, orang yang telah mempelajari hipnosis dalam kesehariannya dan memperdalam keilmuan hipnosis juga terlalu fanatik terhadap berbagai teknik yang "luar biasa" dan dapat digunakan untuk menuntaskan berbagai permasalahan, sampaisampai segala macam penyakit baik fisik maupun non fisik diyakini hanya dapat dituntaskan dengan teknik hipnosis. Padahal setiap hal memiliki ranahnya masing-masing. Hipnosis merupakan salah satu dari berbagai ragam cara dalam meningkatkan kualitas mental dan spiritual hidup seseorang. Hipnosis juga dapat menjadi pilihan yang sangat baik bagi siapa saja yang menginginkannya untuk terlibat dengan terapi komplementer untuk meningkatkan kinerja seseorang (Sparks, 2017).

Sebenarnya semua orang bisa melakukan hipnosis, akan tetapi banyak yang tidak menyadari. Hipnosis pada intinya membuat orang lain yakin terhadap apa yang orang katakan, dan orang yang mendengar mampu terbawa pada apa yang dikatakan orang tersebut. Hal itu dikarenakan alam bawah sadar seseorang mampu berada pada kondisi alpha.

\section{METODE PELAKSANAAN}

Metode yang digunakan dalam pemecahan permasalahan termasuk metode analisis. Metode-metode yang digunakan dalam penyelesaian kegiatan dituliskan di bagian ini.

Sebagai langkah awal, mengumpulkan bahanbahan yang terkait dengan pelatihan dan bukubuku teori dan praktek pendukung mengenai dan teori kesadaran dan hipnoterapi.

Langkah kedua, menyiapkan media belajar dengan metode hipnotherapy berupa modul, alat peraga tertentu akan dilakukan proses review untuk makalah yang akan digunakan oleh ahli di bidang pendidikan serta psikologi perkembangan dengan tujuan mendapatkan keabsahan dan memastikan bahwa media belajar ini memang sesuai dan layak untuk dipakai oleh tim sebagai media belajar.

Langkah ketiga yaitu melakukan kegiatan bermain sambil belajar (learning by doing) ke khalayak sasaran yaitu para guru di Kota Malang Jawa timur. Sebagai wilayah awal program sosialisasi dan atas permintaan kepada fakultas.

Evaluasi proses penyesuaian dan hasil akhir media belajrabdilakukan dengan cara melakukan uji validitas tampang dan isi (Face Validity dan Content Validity) program dengan melakukan uji ahli (Expert Judgment). Setelah itu, berikutnya akan dilakukan penyiapan modul dan bahan pelatihan yang efektif

\section{Alur Kegiatan}

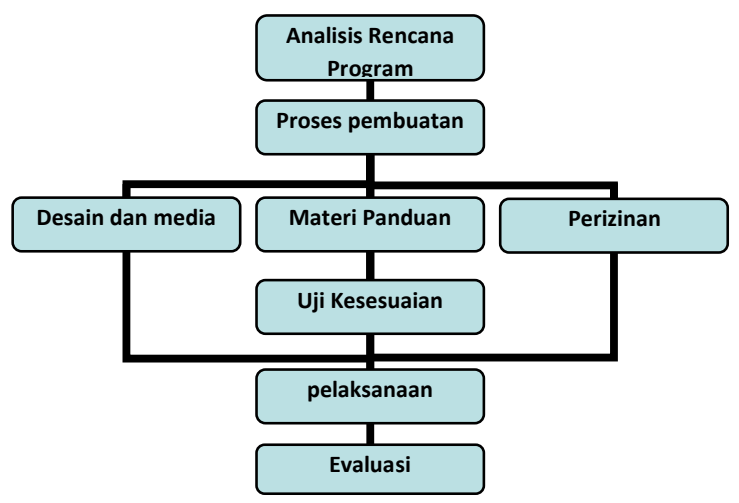




\section{HASIL DAN PEMBAHASAN}

Pengabdian masyarakat yang dilakukan pada Sekolah Menengah Pertama 11 Islam Kota Malang Jawa Timur. Pengabdian ini memberikan hasil yang menyenangkan dengan terlihat adanya partisipasi aktif dari para guru peserta pelatihan dan dukungan dari manajemen sekolah. Antusiasme yang tinggi untuk terlibat dan melakukan roleplay serta membuat catatan-catatan penting selama pelatihan hipnoteaching berlangsung.

Guru-guru peserta pelatihan mampu dengan baik dan memperagakan serta mensimulasikan bersama teman-teman guru lainnya secara bergantian sebagai keingintahuan dan partisipasinya di dalam kegiatan hipnoteaching ini.

Seperti yang kita ketahui, mendidik anak SMP di masa pancaroba dan aqil baligh dengan banyak usaha penentangan terhadap sistem dan aturan yang ada, membuat kebutuhan dalam memiliki ketrampilan mengelola perhatian dan kesadaran sebagai bagian yang dianggap perlu dimiliki oleh para guru SMP ini, khususnya di SMP 1 Islam kota malang.

Penggunaan metode hipnoteaching sebagai sarana belajar sangat tepat untuk sasaran tingkatan usia remaja. Pada sesi pelatihan yang dilakukan oleh para guru yang melihat kebutuhannya untuk menguasai hipnoteaching bersemangat mengikuti setiap sesi dan roleplay yang telah disiapkan oleh tim pengabdian masyarakat dari Fakultas Pendidikan Psikologi UNJ.

\section{PENUTUP}

\section{A. Kesimpulan}

Metode hypnotheraphy telah terbukti mempunyai beraneka manfaat dan kegunaan untuk mengatasi berbagai permasalahan yang berhubungan dengan emosi dan tingkah laku. Permasalahan Yang muncul di dunia pendidikan khususnya di SMP yang didominasi oleh remaja akan sangat membantu guru dalam menanggani siswa dan keberhasilannya dalam proses belajar mengajar.

Hypnotherapy juga bermanfaat untuk mengatasi beranekaragam kasus yang berhubungan dengan kecemasan, ketegangan, depresi, phobia, dan untuk menghilangkan beberapa kebiasaan buruk seperti ketergantungan pada obat-obatan, alkohol, ataupun rokok. Dalam kasus phobis, hypnotherapy bisa dipakai untuk mereduksi kecemasan yang mengambil alih kontrol individu atas dirinya. Hal tersebut dapat diwujudkan dengan menciptakan suatu gambaran nyata tentang kondisi yang menyebabkan phobia, tetapi individu tersebut tetap dalam kondisi relaks. Maka, usaha tersebut bisa membantu mereka untuk menyesuaikan ulang reaksi mereka pada kondisi yang menyebabkan phobia menjadi normal dan respons yang lebih tenang.

Khsuusnya dalam pelatihan guru yang menekankan padabidang pendidikan, hypnotheraphy juga bisa diterapkan untuk meningkatkan optimalisasi pembelajaran. Jika diterapkan dalam pembelajaran, hypnotherapy bisa meningkatkan daya ingat, fokus, dan pencapaian tujuan pembelajaran yang optimal.

\section{B. Saran}

Pelatihan ini harus dilakukan secara komprehensif pada saat sedang melaksanakan proses belajar mengajar. Meningkatkan pemahaman guru tentang karakter anak dan kemudian menyelaraskan dengan pelatihan hipnoteaching, dapat dilakukan dengan berbagai cara baik melalui praktek berulangulang, role play, maupun berdiskusi.

Untuk mendukung serta memaksimalkan sebuah pembelajaran dengan metode hypnoteaching, sebaiknya guru juga menguasai materi pembelajaran secara komprehensif. Hal ini dapat dilakukan dengan melibatkan peserta didik secara aktif dalam proses pembelajaran, sebisa mungkin menyampaikan materi secara kontekstual, memberi kesempatan peserta didik melakukan pembelajaran secara kolaboratif, memberi umpan balik secara langsung kepada peserta didik. Tidak kalah penting pemberian motivasi dan sugesti positif harus sering dilakukan selama pembelajaran berlangsung. 
Langkah-langkah yang dijelaskan diatas memberikan gambaran bahwa seorang guru yang tidak mempunyai rasa cinta terhadap profesi dan rasa cinta terhadap peserta didik akan terasa kesulitan dalam melakukan hal itu, karena metode hypnoteaching bukanlah metode yang membutuhkan fisik guru saja, akan tetapi membutuhkan psikis guru yang harus stabil. Karena metode hypnoteaching menuntut guru menyelaraskan unsur fisik dak psikis guru.

Hal itu bisa dilihat dari bagaimana guru melakukan langkah memberikan motivasi kepada peserta didik, guru yang motivasinya dengan cepat diterima peserta didik adalah guru yang mampu memotivasi diri sendiri karena guru yang tidak memotivasi peserta didik akan terlihat dari ketidak konsistenan antara apa yang diucapkan guru dengan mimik muka guru.

\section{DAFTAR PUSTAKA}

Gunawan, Adi W. (2010) Hypnotherapy for Children: Cara Mudah dan Efektif Menerapi Anak : Gramedia Pustaka Utama

Hakim, Andri (2010) Hypnosis in Teaching, Cara Dahsyat mendidik dan mengajar ; Visi Media

Rodli, A. F. (2017). Deradicalism Of Religious Through Hebat (Hypnotherapy, E-Learning, Guidance Of Religious Actualization And Information Technology). ADRI International Journal of Islamic Studies and Social Sciences, 1(1).

Tellegen, A., \& Atkinson, G. (1974). Openness to absorbing and selfaltering experiences (" absorption"), a trait related to hypnotic susceptibility. Journal of abnormal psychology, 83(3), 268.

Yustisia, N ,(2010) Hypnoteaching seni mengeksplorasi otak peserta didik; Jogjakarta : Ar-ruzz Media,

Sparks, K. (2017). Complementary Therapies in Libraries: A Future Perspective. Urban Library Journal, 23(2), 2. 